\title{
ANALISIS PENDAPATAN USAHATANI TUMPANG SARI KENTANG DI KECAMATAN PANGALENGAN KABUPATEN BANDUNG
}

\author{
Santi Sulistya Nugraheni ${ }^{1}$, Netti Tinaprilla ${ }^{1}$ \\ 1) Departemen Agribisnis, Fakultas Ekonomi dan Manajemen, Institut Pertanian Bogor \\ Jl. Kamper Kampus IPB Darmaga W4L5 Darmaga Bogor 16680 \\ Email: netti_tinaprilla@apps.ipb.ac.id
}

\begin{abstract}
ABSTRAK
Pertanian menggunakan berbagai sistem untuk meningkatkan efisiensi dan produktivitas tanaman. Efisiensi lahan dapat ditingkatkan dengan teknologi dan pola tanam. Polikultur merupakan salah satu sistem tanam untuk meningkatkan produktivitas buah. Penelitian ini bertujuan untuk menganalisis pendapatan usahatani kentang dengan sistem monokultur dan tumpang sari yang berlokasi di Kecamatan Pangalengan, Kabupaten Bandung. Hasil penelitian menunjukkan bahwa usahatani kentang dengan pola tanam tumpang sari memiliki pendapatan yang lebih tinggi dibandingkan dengan budidaya monokultur. Pendapatan total biaya yang diperoleh pada pola monokultur adalah Rp 105.563.346 dengan nilai R/C total biaya sebesar 2.24/ha dalam satu musim tanam. Sedangkan pada pola tanam tumpang sari dengan tanaman cabai total biaya yang diperoleh sebesar Rp 135.345.150 dengan nilai R/C dari total biaya sebesar 2.55/ha dalam satu musim tanam. Kesimpulannya adalah penanaman kentang dengan pola tanam tumpang sari lebih menguntungkan dari pada monokultur di Kecamatan Pangalengan Kabupaten Bandung.
\end{abstract}

Kata kunci: monokultur, pertanian tumpang sari, kentang, analisis pendapatan

\section{PERNYATAAN KUNCI}

Penggunaan pola tanam tumpang sari akan meningkatkan produktivitas lahan yang semakin kecil ini. selain untuk mendukung program diversifikasi pertanian pemerintah, penggunaan sistem tumpang sari ini juga dapat memberikan keuntungan bagi petani dalam beberapa aspek seperti dalam manajemen risiko harga komoditas yang anjlok, dan alasan yang menjadi pertimbangan petani untuk menerapkan pola tanam ini adalah pola tumpang sari dapat menjaga aliran kas dari petani untuk menutup biaya-biaya dan faktor produksi usahatani. Oleh karena itu, penelitian ini ingin menganalisis pendapatan usahatani pada kasus komoditas kentang dikarenakan jenis komoditas ini merupakan komoditas yang memerlukan biaya input yang tinggi pada pola tanam tumpang sari dan dibandingkan dengan analisis usahatani pada pola tanam monokultur. 
Pada penelitian Sutrisna, et. al. (2005) menyebutkan bahwa tinggi tanaman kentang yang dihasilkan dari kedua pola tanam tidak berbeda nyata, dan produksi kentang dengan pola tanam tumpang sari dengan tanaman seledri memiliki hasil yang lebih rendah daripada penggunaan pola tanam monokultur, hal ini dikarenakan adanya persaingan pengambilan unsur hara dalam tanah oleh kedua tanaman. Namun jika dihitung analisis usahataninya, dari berbagai pola tanam dan perpaduan jenis tanaman kentang, seledri, dan bawang daun, pendapatan tertinggi yang dudapatkan yaitu pada pola tanam tumpang sari kentang dengan tanaman seledri. Sehingga untuk membandingkan keunggulan dan kelemahan dalam pola tanam tumpang sari ini dalam analisis ekonominya perlu dilakukan analisis pendapatan usahatani kentang pada pola tanam tumpang sari dan monokultur.

Pada penelitian kali ini, peneliti berfokus pada perbandingan pendapatan usahatani yang menggunakan pola tanam tumpang sari dan pola tanam monokultur pada tanaman kentang untuk mendapatkan kesimpulan pola tanam yang cocok untuk diterapkan pada komoditas kentang di lokasi penelitian. Sehingga produksi dan pendapatan usahatani dapat meningkat. Dari ulasan tersebut dapat dirumuskan permasalahan diantaranya adalah :
1. Apakah terdapat perbedaan pada pendapatan usahatani kentang dengan pola tanam monokultur dan tumpang sari?

2. Usahatani kentang dengan pola tanam manakah yang lebih efisien antara pola tanam monokultur dan tumpang sari?

\section{REKOMENDASI KEBIJAKAN}

Penggunaan pola tanam tumpang sari dengan tanaman cabai belum dapat memberikan keuntungan yang signifikan dibandingkan dengan pola tanam monokultur, namun penggunaan pola tanam tumpang sari dapat mengatasi permasalahan aliran kas atau cash flow pada petani yaitu petani dapat memperoleh penerimaan sebelum masa panen kentang.

Kepada peneliti adalah perlu dilakukan perbandingan analisis usahatani pada pola tanam tumpang sari dengan tanaman sela yang lain untuk melihat tanaman sela mana yang paling menguntungkan secara ekonomi.

\section{PENDAHULUAN}

Indonesia memiliki keragaman model usahatani dan berbagai pola tanam seperti monokultur, polikultur dan rotasi tanam. Tumpang sari termasuk dalam pola tanam polikultur dengan menanam beberapa jenis tanaman pada lahan dan waktu yang sama, yang diatur sedemikian rupa dalam barisanbarisan tanaman. Penanaman dengan cara ini bisa dilakukan pada dua atau lebih jenis tanaman yang relatif seumur atau berbeda 
dengan penanaman berselang-seling dan jarak tanam teratur pada sebidang tanah yang sama (Warsana, 2009; Prastiyo et al, 2020).

Menurut peraturan Menteri Kehutanan Republik Indonesia Tanaman Tumpang sari adalah tanaman pangan setahun/semusim yang ditanam di antara larikan tanaman pokok dan larikan tanaman kehidupan untuk menekan pertumbuhan gulma dan memperoleh hasil tambahan selama masa menunggu waktu penebangan tanaman pokok dengan jenis tanaman yang memperhatikan kebutuhan masyarakat setempat.

Menurut data BPS tahun 2016 menyatakan bahwa dari 5 komoditas utama holtikultura hanya kentang yang mengalami penurunan produksi. Menurut penelitian Supriyanti (2004) menyebutkan bahwa adanya penurunan kesejahteraan petani kentang di sulawesi selatan yang dinilai dari nilai tukar petani kentang. Penurunan kesejahteraan petani ini dikarenakan karena laju pertumbuhan harga kentang lebih lambat dibandingkan dengan harga yang harus dibayarkan petani untuk barang konsumsi, dan sarana produksi kentang. Selain itu, harga input produksi dari kegiatan usahatani jenis sayuran hortikultura ini semakin meningkat seiring waktu. Untuk menekan dan memanfaatkan penggunaan input pada usahatani, petani seringkali menggunakan modifikasi sistem tanam atau pola tanam yaitu menggunakan pola tanam tumpang sari.

Penurunan produksi kentang dapat disebabkan berbagai faktor, salah satunya juga dikarenakan serangan hama pada tanaman kentang cukup tinggi. Berdasarkan penelitian menyebutkan bahwa tumpang sari tanaman kentang dengan seledri dapat meurunkan tingkat serangan hama pada tanaman kentang. Melihat tingginya penggunaan pestisida pada tanaman kentang sehingga diperlukan teknologi untuk mengurangi penggunaan pestisida namun hama dan penyakit juga dapat ditekan. Salah satu teknologi yang dapat digunakan adalah dengan menerapkan pola tanam tumpang sari ini. Penggunaan teknologi seperti penggunaan pola tanam tumpang sari dapat mengurangi serangan OPT pada tanaman tertentu.

Komoditas kentang menjadi salah satu komoditas unggulan di Kabupaten Bandung dengan luas tanam, luas panen, dan jumlah produksi tertinggi diantara produk hortikultur lainnya. Salah satu wilayah yang banyak ditanami oleh tanaman kentang adalah di Kecamatan Pangalengan yang terletak di bagian Bandung Selatan yang memiliki suhu dingin karena berada di dataran tinggi sehingga cocok untuk budidaya tanaman kentang. Tanaman kentang menjadi salah satu komoditas unggulan di Kabupaten Bandung, dengan jumlah produksinya mencapai 93968 ton 
dan produktivitasnya mencapai 186,19 kwintal per hektar atau setara dengan 18 ton per kilogram dimana produktivitas budi daya kentang di Bandung setara dengan produktivitas budi daya kentang di Indonesia.

Karena menjadi salah satu komoditas unggulan, banyak petani di Kabupaten Bandung terutama di Kecamatan Pangalengan yang memilih untuk menanam tanaman kentang sebagai komoditas usahatani mereka. Pola tanam yang digunakan juga berbagai macam. Petani yang menggunakan pola tanam monokultur biasanya memiliki lahan yang luas sehingga akan mempermudah penanganan dalam proses on farm, namun petani yang memiliki lahan sempit akan menggunakan pola tanam tumpang sari untuk memaksimalkan produksi lahannya.

\section{SITUASI TERKINI}

\section{Keragaan Usahatani Kentang}

Jenis tanaman yang paling sering dibudidayakan oleh petani sayuran di Kecamatan Pangalengan adalah jenis tanaman kentang, kubis, wortel, bawang daun dan tomat. Dalam musim tanam pertama pada satu tahun tanam yaitu pada bulan Januari, petani akan menanam tanaman kentang yang 4 bulan kemudian akan dilakukan pergiliran tanaman dengan mengganti komoditas yang ditanamnya. Petani yang pada masa tanam pertama menanam tanaman kentang maka musim tanam berikutnya akan mengganti dengan tanaman kubis atau wortel. Pergiliran tanaman ini bertujuan untuk mengembalikan zat hara tanah yang telah digunakan tanaman kentang sebelumnya dan memutus siklus hidup dari hama dan penyakit yang menyerang tanaman kentang. Kemudian setelah musim tanam tanaman wortel atau kubis, petani dapat menanam tanaman kentang kembali di lahan tersebut.

Sebagian besar petani responden menggunakan jenis pola tanam monokultur atau satu jenis tanaman dalam lahan usahatani nya. Penggunaan pola tanam tumpang sari dengan tanaman utama adalah kentang dan tanaman tumpang sarinya adalah tanaman lain masih sangat jarang digunakan oleh petani di Kecamatan Pangalengan ini sendiri. Dari responden yang diperoleh 53 diantaranya menggunakan pola tanam monokultur sedangkan petani yang menggunakan pola tanam tumpang sari pada lahan usahataninya hanya sebanyak 3 orang.

\section{Pola Tanam Tumpang sari Kentang Dengan Tanaman Cabai}

Usahatani kentang dengan penerapan pola tanam tumpang sari atau polikultur di Kecamatan Pangalengan ini dilakukan oleh tiga petani responden dengan tanaman sela yang dipilih adalah tanaman cabai. Tanaman cabai dipilih petani dikarenakan harga jual cabai di tingkat petani yang sedang tinggi. Petani menggunakan jarak tanam antar 
tanaman utama adalah 80 x $30 \mathrm{~cm}$ sedangkan tanaman sela ditanam disela-sela barisan tanaman utama dengan jarak tanam menjadi 40 x $30 \mathrm{~cm}$. Tanaman cabai ditanam dua minggu sebelum tanaman kentang ditanam, hal ini dikarenakan perkecambahan tanaman cabai lebih lambat daripada tanaman kentang sehingga perlu ditanam lebih awal agar ketika tanaman kentang mulai ditanam, tanaman cabai tidak tertutup oleh tajuk tanaman kentang.

\section{Analisis Penerimaan Usahatani Kentang dengan Pola Tanam Monokultur dan Tumpang sari}

1. Penerimaan Usahatani Kentang Monokultur

Penerimaan tunai usahatani kentang pada petani di Kecamatan Pangalengan diperoleh dari tiga jenis penjualan yang berbeda yaitu kentang untuk produksi benih dimana petani menjual kentang yang berukuran kecil dalam bentuk benih. Kentang yang dijual dalam bentuk benih ini kemudian akan disimpan terlebih dahulu selama dua bulan di gudang, kemudian baru bisa dijual kepada pedagang penangkar atau tengkulak. Kentang yang dijual dalam bentuk benih ini merupakan kentang keturunan berikutnya dari kelas benih kentang yang ditanam petani. Sehingga harga jual kentang benih ini bermacam-macam dari Rp 20 000 hingga Rp 30 000/kg tergantung pada kelas benih yang dimiliki. Rata- rata penerimaan tunai petani yang diperoleh dari penjualan kentang benih adalah sebanyak Rp 71889561 dengan produksi kentang benih rata-rata sebanyak $3 \quad 917.1 \quad \mathrm{~kg}$. kemudian penerimaan petani berikutnya adalah kentang sayur dimana petani menjual kentang sebagai sayur bukan sebagai benih. Kentang sayur memiliki ukuran yang proporsional dan tidak banyak cacat baik kulit maupun daging umbinya. Produksi kentang sayur oleh petani mencapai rata rata $12189.46 \mathrm{~kg}$ dengan harga pasar rata-rata adalah $\mathrm{Rp}$ 7000 sehingga diperoleh penerimaan sebesar Rp 85326215.

Penerimaan dari kentang sayur lebih besar daripada penerimaan dari kentang benih dimana kentang benih memberikan $37.68 \%$ dari total penerimaan dan kentang sayur memberikan $44.73 \%$ dari total penerimaan. Penerimaan dari kentang benih cukup tinggi dikarenakan harga kentang benih yang lebih tinggi, namun kentang benih memliki waktu tunggu hingga dapat dijual. Kentang yang memiliki ukuran tidak seragam dan banyak cacat di kulit dan buahnya namun masih layak biasanya akan dijual dalam bentuk kentang afkir yang harga jualnya lebih rendah dari kentang sayur. Rata-rata penerimaan dari kentang afkir ini adalah sebesar Rp 1468078 dari 
harga jual rata-rata sebesar Rp 2000 . Kentang afkir ini dijual kepada industri olahan kentang seperti kerupuk kentang dan lain-lain. Penjualan utama kentang sayur adalah pada tengkulak yang mendatangi lokasi lahan para petani dimana antara petani dan tengkulak sudah bernegosiasi mengenai harga jual yang dikenakan sebelum dilakukan panen berdasarkan pertimbangan harga pasar. Penjualan kentang bentuk benih adalah kepada tengkulak benih kentang atau penangkar benih kentang serta petanipetani sekitar yang bersedia membeli. Sedangkan penerimaan non tunai merupakan penerimaan dari hasil produksi yang digunakan kembali untuk benih di musim tanam berikutnya. Hasil benih yang akan digunakan rata-rata menghasilkan sebesar Rp $1838.45 \mathrm{~kg} / \mathrm{ha}$ per musim tanam dengan hasil penerimaan non tunai sebesar Rp 32086 236, yang merupakan perkalian dari total benih yang akan digunakan dengan harga rata-rata penjualan benih. Total penerimaan yang dihasilkan dari usahatani kentang dengan pola monokultur adalah sebesar Rp 190770 090 per ha per musim tanam.

2. Penerimaan Usahatani Kentang Tumpang Sari dengan Cabai
Penerimaan tunai usahatani kentang dengan pola tanam tumpang sari yaitu dengan tanaman cabai menghasilkan total penerimaan ratarata sebesar Rp 171395714 / ha per musim tanam. Penerimaan tersebut diperoleh dari penerimaan usahatani dengan tanaman utama adalah kentang dan tanaman tumpang sari atau tanaman sela adalah cabai. Penerimaan dari tanaman kentang terdiri dari penerimaan dari kentang benih yaitu sebesar Rp 44005714 atau sekitar $19.78 \%$ dari total penerimaan. Untuk kentang sayur yang diproduksi yaitu sebanyak $4753 \mathrm{~kg} / \mathrm{ha}$ dengan harga rata-rata sebesar Rp 9000 sehingga menghasilkan penerimaan sebesar Rp 42774000 dimana merupakan $19.23 \%$ dari total penerimaan. Kentang afkir dari usahatani kentang dengan pola tumpang sari menghasilkan penerimaan Rp 722 667. Komponen penerimaan tunai selain dari tanaman utama berasal dari penerimaan tanaman sela yaitu tanaman cabai. Penerimaan dari tanaman tumpang sari yaitu tanaman cabai sebesar Rp 83893 333. Penerimaan dari tanaman tumpang sari ini cukup besar dikarenakan pada musim tanam terakhir, harga cabai sedang tinggi mencapai harga Rp $22000 \quad / k g$ sedangkan produksi cabai untuk satu 
hektar lahan mencapai rata-rata 9 ton/ha. Cabai dipanen hingga mencapai 36 kali pemanenan dengan kuantitas pemanenan yang berbeda beda, tanaman kentang yang selesai dipanen kemudian dicabut, namun tanaman cabai yang memiliki umur tanam lebih lama tetap dibiarkan tumbuh hingga masa tanamnya berakhir yaitu tanaman cabai akan dicabut pada musim panen kentang kedua setelah tanaman rotasi yaitu tanaman kol. Penerimaan non tunai berasal dari penerimaan benih kentang yang akan digunakan sebagai benih di musim tanam kentang selanjutnya yaitu sebesar Rp 51047619 /ha per musim tanam.

Produktivitas kentang yang dihasilkan dari kedua jenis pola tanam menunjukkan hasil yang cukup berbeda. Hal ini dikarenakan pada pola tanam tumpang sari memiliki jarak tanam antara tanaman kentang yang lebih besar daripada jarak tanam tanaman kentang pada pola tanam monokultur sehingga menyebabkan populasi tanaman kentang pada pola tanam tumpang sari lebih kecil dibandingkan pada pola tanam monokultur. bahwa produktivitas kentang pada pola tanam monokultur sebesar $18472.27 \mathrm{~kg} / \mathrm{ha}$ per musim tanam sedangkan pada pola tanam tumpang sari hanya menghasilkan sebanyak $9866.67 \mathrm{~kg} / \mathrm{ha}$ per musim tanam. Jarak tanam tanaman kentang pada pola tanam monokultur adalah sebesar $30 \times 30 \mathrm{~cm}$ sedangkan pada pola tanam tumpang sari adalah sebesar 80 x $30 \mathrm{~cm}$. Hal ini menyebabkan populasi tanaman kentang pada luas lahan satu hektar berbeda pada kedua pola tanam sehingga produksi kentang yang dihasilkan pada pola tanam tumpang sari lebih rendah daripada produksi kentang pada pola tanam monokultur. Menurut penelitian Herlina (2017), menunjukkan bahwa tanaman cabai yang ditumpangsarikan dengan tanaman kubis menjadi lebih dominan dalam memanfaatkan faktor tumbuh dibandingkan dengan tanaman kubis. Sehingga untuk tanaman Sayuran lainnya seperti kentang memiliki kemungkinan besar produksinya berkurang dikarenakan tanaman sela yang tidak cocok dengan tanaman utama. Hal ini juga bisa menjadi pemicu rendahnya produktivitas tanaman utama pada pola tanam tumpang sari terlebih dengan tanaman cabai.

\section{Komparasi Pendapatan Usahatani Kentang pada Pola Tanam Monokult0r dan Tumpang sari}

Perbandingan pendapatan dan nilai $\mathrm{R} / \mathrm{C}$ pada usahatani kentang dengan kedua pola tanam. Pendapatan usahatani atas biaya 
tunai pada pola tanam monokultur menunjukkan nilai yang lebih rendah daripada pendapatan usahatani atas biaya tunai pada pola tanam tumpang sari. Begitu juga untuk pendapatan atas biaya total pada pola tanam monokultur menunjukkan nilai yang lebih rendah daripada pada pola tanam tumpang sari. Hal ini menunjukkan bahwa usahatani kentang dengan pola tanam tumpangsari lebih menguntungkan daripada menggunakan pola tanam monokultur yang mana pada kasus ini pola tanam tumpang sari menggunakan tanaman sela cabai.

Pada analisis nilai $\mathrm{R} / \mathrm{C}$ juga menunjukkan nilai $\mathrm{R} / \mathrm{C}$ atas biaya tunai untuk usahatani kentang dengan pola tanam monokultur menunjukkan nilai yang lebih rendah daripada penggunaan pola tanam tumpang sari. Nilai $\mathrm{R} / \mathrm{C}$ atas biaya total pada usahatani kentang dengan pola tanam monokultur juga menunjukkan nilai yang lebih rendah daripada nilai $\mathrm{R} / \mathrm{C}$ atas biaya total pada pola tanam tumpang sari. Nilai R/C yang lebih tinggi pada usahatani dengan pola tanam tumpang sari ini menunjukkan efisiensi usahatani pada pola tanam tumpang sari lebih tinggi atau lebih efisien daripada penggunaan pola tanam monokltur. Efisiensi yang lebih tinggi pada pola tanam tumpang sari ini dikarenakan penggunaan faktor produksi seperti lahan, obat-obatan, dan lain-lain dapat digunakan lebih efisien dan menghasilkan penerimaan yang lebih tinggi daripada penggunaan pola tanam monokultur.

Menurut Darmawan et al. (2014) berdasarkan aspek pendapatan bersih, menunjukan rata- rata pendapatan bersih petani sayuran di desa Jatimulyo yang melakukan diversifikasi dengan yang tidak melakukan diversifikasi (monokultur) memiliki perbedaan. Petani sayuran yang melakukan diversifikasi memiliki rata- rata pendapatan bersih yang lebih besar daripada petani sayuran yang tidak melakukan diversifikasi (monokultur). $\mathrm{Hal}$ ini menunjukkan bahwa tumpang sari dianggap lebih menguntungkan dibandingkan pola tanam monokultur. Menurut penelitian yang dilakukan Pinem (2005) menunjukkan bahwa dari beberapa jenis tanaman yang digunakan sebagai tanaman tumpang sari dengan tanaman kentang yaitu tanaman jagung, buncis, bayam, dan serai, tanaman yang memberikan dampak positif terhadap pertumbuhan kentang dan mengurangi serangan hama pada tanaman kentang adalah tanaman serai. Meskipun demikian, namun terdapat penurunan produksi tanaman utama yaitu tanaman kentang selain dikarenakan populasi tanam yang lebih kecil pada pola tanam tumpang sari, hal ini juga dikarenakan pemilihan tanaman sela yang kurang tepat. Berdasarkan keterangan Vandania (2014), tanaman kentang yang ditumpang sarikan dengan tanaman cabai menunjukkan penurunan 
produksi begitu pula dengan tanaman cabai tidak dapat berproduksi secara maksimal.

\section{REFERENSI}

Ajayi, J.O. 2014. Comparative Economic Study of Mixed and Sole Cassava Cropping Systems in Nigeria. Jurnal Agris on-line Papers in Economics and Informatics.6 (1) : 15-23

Anggitasari, A. 2016. Perbandingan Pendapatan Usahatani Monokultur Sayuran dengan Usahatani Tumpang sari Kopi dan Sayuran di Desa Margamulya, Kecamatan Pangalengan, Kabupaten Bandung. [Skripsi]. Bogor (ID): Institut Pertanian Bogor

Darmawan, A., Sedyati, R., Suyadi, B. 2014. Perbedaan Pendapatan antara Petani yang Melakukan dengan yang Tidak Melakukan Diversifikasi Usahatani. [Skripsi]. Jember (ID): Universitas Jember

Darwis, K. 2017. Ilmu Usahatani Teori dan Penerapan. Makassar (ID): Inti Mediatama

Hernanto, F. 1991. Ilmu Usahatani. Penebar Swadaya. Jakarta.

Idani, F.R. 2012. Analisis Pendapatan Usaha Tani dan Optimalisasi Pola tanam Sayuran di Kelompok Tani Pondok Menteng Desa Citepen, Kecamatan Ciawi Kabupaten Bogor, Jawa Barat. [Skripsi]. Bogor (ID): Institut Pertanian Bogor

Nuraisyiah, C. 2013. Penggunaan Berbagai Ukuran dan Periode Simpan Umbi Kentang Bibit (Solanum tuberosum L.). [Skripsi]. Bogor (ID): Institut Pertanian Bogor

Perdana, M. 2011. Analisis Komparatif Usahatani Tumpang sari Jagung dan Kacang Tanah dengan Monokultur Jagung di Kabupaten Wonogiri [Skripsi]. Surakarta (ID): Universitas Sebelas Maret
Pinem, I. 2005. Beberapa Jenis Tanaman Tumpang Sari dalam Menekan Serangan Hama Liriomyza sp pada Tanaman Kentang (Solanum tuberosum L.). [Skripsi]. Medan (ID): Universitas Sumatera Utara

Rahma, S., Ilat, V., dan Tirayoh, V. 2017. Analisis Alokasi Biaya Bersama dalam Penentuan Harga Pokok Produksi pada UD. Totabuan Kacang Goyang Burung Maleo. Jurnal EMBA. 5(2) : $1512-1519$

Ratnasari, I. 2016. Analisis Pendapatan dan Optimalisasi Pola tanam Usahatani Sayuran. [Skripsi]. Bogor (ID): Institut Pertanian Bogor.

Prastiyo, Y.B., Kaswanto, R.L., Arifin, H.S., 2020. Plants Diversity of Agroforestry System in Ciliwung Riparian Landscape, Bogor Municipality. In IOP Conference Series: Earth and Environmental Science 477 (1), p. 012024. IOP Publishing.

Shinta, A. 2011. Ilmu Usahatani. Malang (ID): UB Press

Suginarti. 2004. Tumpang Sari Padi dengan Beberapa Jenis Kacang-kacangan pada Budidaya Jenuh Air. [Skripsi]. Bogor (ID): Institut Pertanian Bogor

Sukma, S., Nawawi, M., dan Herlina, N. 2013. Pengaruh saat Tanam Jagung dalam Tumpang sari Tanaman Jagung (Zea mays L.) dan Brokoli (Brassica oleracea L. var. botrytis). Jurnal Produksi Tanaman. 1(3) : 8792

Suryanto, H., Maryunianta, Y., Ayu, S. 2018. Analisis Perbandingan Usahatani Antara Pola Tanam Tumpangsari Cabai Merah Keriting dan Kubis Krop dengan Monokultur Cabai Merah Keriting. Journal on Social Economic of Agriculture and Agribusiness. 9(2): 1 - 15

Sutrisna, N., Sastraatmadja, S., dan Ishaq, I. 2005. Kajian Sistem Penanaman 
Tumpang sari Kentang (Solanum Tuberosum L.) di Lahan Dataran Tinggi Rancabali, Kabupaten Bandung. Jurnal Pengkajian dan Pengembangan Teknologi Pertanian. 8(1) : 78 - 87

Tri, D. 2016. Kajian Ekonomi antara Pola Tanam Monokultur dan Tumpangsari Tanaman Jagung, Kubis dan Bayam. Jurnal INOVASI. Vol.18 No.1: 66-71
Vandania. 2014. Tumpangsari KentangCabe atau Penangkaran Benih Kentang? Kasus 1 [Internet]. Bogor (ID): [diunduh 2018 Mei 27]. Tersedia pada http://www.vandaniasekar.blogspo t.co.id/2014/06/tumpangsarikentang-cabe-atau.html

Warsana. 2009. Introduksi Teknologi Tumpangsari Jagung dan Kacang Tanah. Jakarta (ID): Sinar Tani 